Europe's Journal of Psychology 2/2009, pp.96-109

www.ejop.org

\title{
Chôra: Creation and Pathology \\ An Inquiry into the Origins of Illness and Human Response
}

\author{
Nicoletta Isar \\ Institute of Art History \\ University of Copehangen
}

\begin{abstract}
Plato's dialogue the Timaeus describes not only the making of the cosmos (order), but also the condition of what is not order, neither for the human body nor for the universe. What is disorder in cosmogonic terms it is disease for the human body. Timaeus applies to the concept chôra in discussing the origins of disease as a state of imbalance and shaking, because the cosmogonic chôra is replicated in the human body, more exactly, in the liver. But the liver is also the organ of divination, the gift given to man to have access to some hidden truth. This article attempts to sketch out the relation between the chôra and illness, looking for an answer to the question of what light might shed the relationship between chôra and illness on human creativity. A specific human typology, subject to disturbances taking place in the chôra, is examined: the poet, the diviner and the melancholy artist, manifested as channels of some exceptional inspiration. They are "mantic subjects" because they acquire vision of divination not with reason, but in a state of inspiration, through divine madness (manía) and possession, as in a dream. These subjects turn illness into creativity by facing the drives of chôra.
\end{abstract}

Socrates. One, two, three; but where, my dear Timaeus, is the fourth of those who were yesterday my guests and are to be my entertainers to-day?

Timaeus. He has been taken ill, Socrates; for he would not willingly have been absent from this gathering. (Tim. 17a)

That many of Plato's texts, in particular the Timaeus, were treated by the later generations as important medical texts should be of no surprise. Timaeus includes a 
most elaborate account of physiology, as well as of aetiology of disease influenced by Greek medical theory. But Plato's aetiology and his vision of human pathology exceed by far the field of medical science. It reaches out to the abstract thinking of the Socratic paradoxes, which are at the foundation of Plato's conception of creation, connecting mental and physical health. The limited space of this article will only allow me to sketch out the pathological aspects implicit in his paradigm of creation. With the assistance of the chôra, I will look into the Timaeus from the perspective of illness, as Plato himself makes a point about the absent person in the dialogue due to his illness. The question of the absent fourth person in the dialogue might be a strong indication that Plato is putting the accent on the notion of absence of space, which is true, but the person is absent due to his illness, and this also explains why Timaeus will turn to illness in the third discourse of the dialogue.

It must be stressed from the beginning that Plato's dialogue Timaeus is about the creation of the universe and the creation of man, both fashioned according to the principle of likeness with the Demiurge. In the dramatic process of transition from the intelligible and invisible world to the visible cosmos (the orderly universe) the concept chôra is instrumental. Chôra is the nurse, the matrix (ekmageion), the womb and the receptacle in which creation takes place. She is a third kind of reality (tríton génos), a space-in-the-making, and in-between, because she partakes both of the intelligible, and the phenomenal bodies visiting her in the process of creation. Let us describe this cosmological process and the principle that governs it as it will have high relevance for my further research.

Before the universe comes to be generated out of the four main elements (fire, water, earth, air), the traces of these elements are set apart form each other in different regions. The crucial detail in the cosmic drama is that the phenomenal bodies visiting the chôra are in constant and complex motion. This movement derives from the difference of the powers (dynamis) manifested within the chôra, which shakes her and, in turn, she shakes them, as in the description: "the Nurse of Becoming, being liquefied and ignified are receiving also the forms of earth and of air, and submitting to all the other affections which accompany these, exhibits every variety of appearance; but owing to being filled with potencies that are neither similar nor balanced, in no part of herself is she equally balanced, but sways unevenly in every part, and is herself shaken by these forms and shakes them in turn

\footnotetext{
${ }^{1}$ Aetiology is the study of the causes of diseases or pathologies. Pathology is the study and diagnosis of disease through examination of organs, tissues, cells and bodily fluids.
} 
as she is moved" (52d-52e). In their passage through chôra, the phenomenal bodies leave their traces behind, and this is instrumental in disclosing the absconded chôra. However, the chôra appears only episodically to sight, only the moments when these bodies collide with her. She appears only in the traces since only the things that move are visible things and leave their traces in the visible. One could therefore speak of the chôra only in movement, as the moving trace of the chôra. But at the same time, it is fair to say that the trace of the chôra is an impermanent trace.

Such picture of the chôra precedes the cosmic order, but this does not necessarily mean that there is disorder in chôra. Rather, there is a different principle at work. Let us try to identify now this principle since the same principle will be at work in the human body. To describe the movements inside chôra, how the elements (shapes, characters, forces, traces), still in a primordial state, move and liquefy or ignify chôra, Plato uses the metaphor of "the sieve." Thus he writes: "the forms, as they are moved, fly continually in various directions and are dissipated; just as the particles that are shaken and winnowed by the sieves and other instruments used for the cleansing of corn fall in one place if they are solid and heavy, but fly off elsewhere if they are spongy and light (52e-53a). With the sieve one can separate heavy and thick parts of corn from the scarce and light, but as we will see in a moment, the primordial elements take quite a specific turn in their motion: "her motion, like an instrument which causes shaking, was separating farthest from one another the dissimilar, and pushing most closely together the similar; wherefore also these Kinds occupied different places even before that the Universe was organised and generated out of them" (53a). This description shows how movement inside chôra can't be defined properly as chaotic in the sense of ultimate disorder; rather, in chôra a metaphysical order of some other kind is reigning. The primordial elements get closer or further following the principle of similarity. They tend to get closer to those more similar, and to get further from the different in a continuous movement.

The Origins of Disease

But as it comes out later, in the dialogue, Timaeus inquires not only into the making of the cosmos, that is, order (from Gk. kosmos "orderly arrangement" cf. Homeric kosmeo), but also into the condition of what is not order, neither for the human body, nor for the universe before it becomes the orderly universe. What is disorder in cosmogonic terms it is disease for the human body, which is itself shaped according to the principle of likeness with the god archetype. Timaeus applies once more to 
the concept chôra in discussing the origins of disease. He describes disease as a reversion to that state of imbalance and shaking when, before the arrival of the god creator, the chôra was filled with the traces of fire, air, water, and earth - the four primary bodies of which the human body (like the cosmos) is composed: "When, contrary to nature, there occurs either an excess or a deficiency of these elements or a change in the chôra from the proper to an other, then the body loses its selfsameness, and there results disorders (stáseis) and diseases (nósous)" (Tim. 82a). The disease is the reverse of order and sameness; it is the unlimitedness (apeiron) and the dissembling. The disease is the effect of disorder between body and soul caused by "the very passionate state" of the soul which "shakes the whole body from within and fills it with maladies" (88a).

Let us now come close to the passage in the Timaeus, where the chôra is, according to Sallis, "replicated" within the human body (SALLIS 1999, p. 122). Chôra is replicated in its visual appearance, as well as in its symptoms, in the liver: "To guard against this (i.e. images and phantasms) God devised and constructed the form of the liver and placed it in that part's abode; and He fashioned it dense and smooth (lampros) and bright and sweet, yet containing bitterness, that the power of thoughts that proceed from nous move in the liver as in a mirror that receives impressions and provide visible images, should frighten this part of the soul" (Tim. 71b). The liver receives images from the faculty of understanding dianoia (Tim. 71c), making by contraction the surface of the liver wrinkled and rough, exhibiting thus bilious colours. The liver was possibly introduced into that region by God to be an instrument or intermediary of the highest part of the soul (Tim. 71f.), whereby the latter could show visions and terrify or appease to epithumetikón (the motion of desire) (ONIANS 1954, pp. 87-88). It is why a subsidiary organ is provided, the ekmageion, described as a napkin or a wiping cloth laid besides a mirror, whose primary function is precisely to keep the liver bright and clean (Tim. 72 c).

In so far as the disease is disorder and dissembling, the body therapy should consist of restoring the symmetry and balance between soul and body. As Timaeus puts it: "the one means of salvation is this - neither to exercise the soul without the body nor the body without the soul, so that they may be evenly matched and sound health." Restoration of health could technically be achieved by cultivating music and philosophy "as both deserve to be called truly fair and good" (Tim. 88c). The imitation consists basically of such curative drive, which "never, if possible, allows the body to be at rest but keeps it moving, and by continually producing internal vibrations" (Tim. 88e) to restore the likeness with the model. Only by such continuous movement would man be able to get in tune with the prototype and reflect it. 
Vision in the liver - a mirror image

One must stress that the chief quality of this chôra receptacle described above (the liver) is that to reflect like a mirror. The liver is smooth, shining (lampros), sweet, and bitter. With respect to the body, we may call the physiological process of its cleansing by the term choral technique (MANOLESCU 2001, p. 56). The process imitates the nurse, the cosmic chôra in its primordial cosmogonic process of moulding, which is said to "begin by making it even and as smooth as possible before they execute the work" (Tim. 50e). But the accessibility of this kind of imagemirror refection in the liver is problematic, just like the image of the cosmic chôra. As Plato has already emphasized when describing the making of the cosmos, the chôra could only be grasped with great difficulty through a bastard thinking (logismo nothō) and vision - in Derrida's words - "alternating between the logic of exclusion and that of participation" (DERRIDA 1995, p. 89). To look at the chôra was as if "we look at it as in a dream" (Tim. 52b). One dreams of the chôra, and in the dream one fails to distinguish the three kinds of being, because this is the symptomatology of the dream. Dreaming is, according to Socrates, mistaking an image for its original (Rep. 476c). The dream confounds, but it also discloses that of which one dreams, so that the dream space of chôra is a mere image of chôra, a reflection, not the "chôra itself." The chôra is, according to John Sallis, anything but a mere mirror in which perpetual being would be reflected and the cosmos fabricated (SALLIS 1999, p. 122). As I will show in a moment, this cosmic symptomatology of the chôra applies to the humans as well, because they are shaped according to the same principle: the likeness with the archetype/macrocosmos, which they both reflect. The reflection of the archetype in the body is the vision in the liver described above. This image might be, either a reflection of the selfsameness (order) with the archetype, or one of disorder and dissimilarity, which is the sign of sickness. This vision is man's share of truth, according to Plato. According to the philosopher, man could in some degree lay hold on truth, but on some condition. To have access to some truth, he says, "God gave unto man's foolishness the gift of divination." The shining (lampros) surface of the liver is able to reflect thoughts because the soul in the liver area is capable of divination. But vision of divination is achieved not with reason, but with another faculty: "no man achieves true and inspired divination when in his rational mind, but only when the power of his intelligence is fettered in sleep or when it is distraught by disease or by reason of some divine inspiration" (Tim. 71e). The person having access to such vision, due to his personal affection or disease is called mántis, a diviner. His vision we may call mantic vision. The diviners (mánteis) have the 
experience of inspired divinations (enthéois manteíais), and the prophets (prophetes) are the interpreters (upokritail) of these visions (Tim. 71e-72b).

It is interesting to note that the ancient Babylonians considered the liver - though not the human organ, but of a sacrificial sheep (amutu) - to be the "mirror of Heaven," and to be apt for divination. Babylonian Hepatoscopy (the examination of the visceral surface of the liver) was the highest form of the diviner's art, which divided the surface into various zones (Fig. 1). It was believed that, by magic sympathy, the state of the organ showed the state of mind of the god, who at the moment of sacrifice was believed to have identified himself with the victim (ONIANS 1954, p. 60). Etruscan divination by the liver, followed by the Romans, has some affinities to the Babylonian culture. The overwhelming number of bronze mirrors found in the Etruscan culture could not only be explained by a rise of demand of cosmetic objects. Their circular shape, the polished mirror surface, as well as, in many cases, the iconography explicitly related to divination, and decorating the surface opposite to the reflecting part of the mirror, make them most interesting cases of choral technique. One example stands out: the bronze mirror from Vatican City, Museo Gregoriano Etrusco, showing Calchas, the priest of Apollo, mentioned in Homer's lliad - an elderly haruspex ${ }^{2}$ examining the liver of a sacrificed sheep (Fig. 2). The Etruscan inscription reads his name Xalxas (Chalchas), and the caption: A winged soothsayer incised on a bronze mirror reads omens from an animal's liver. The mythical Greek soothsayer Chalchas is represented with the attribute of wings, stressing his function of go-between earthly and transcendental reality. His posture, one foot on the rock upwards, and the other one touching the earth, suggests his interstitial placement in the chôra, the in-between space where divination takes place performed by the haruspex, who is able to establish contact between the two worlds.

2 Haruspex (plural haruspices) was a soothsayer or diviner who practiced a special form of divination called haruspicy. Haruspicy was the interpretation of the entrails of sacrificed animals, especially the livers of sacrificed sheep, therefore this kind of divination was called also hepatoscopy. 


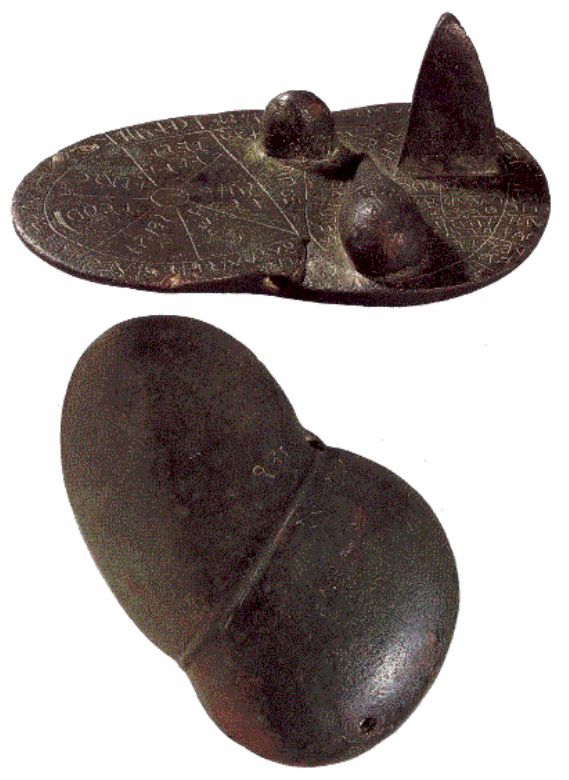

Fig. 1 Piacenza Bronze Liver used for divination in hepatoscopy (Piacenza Museo Civico)

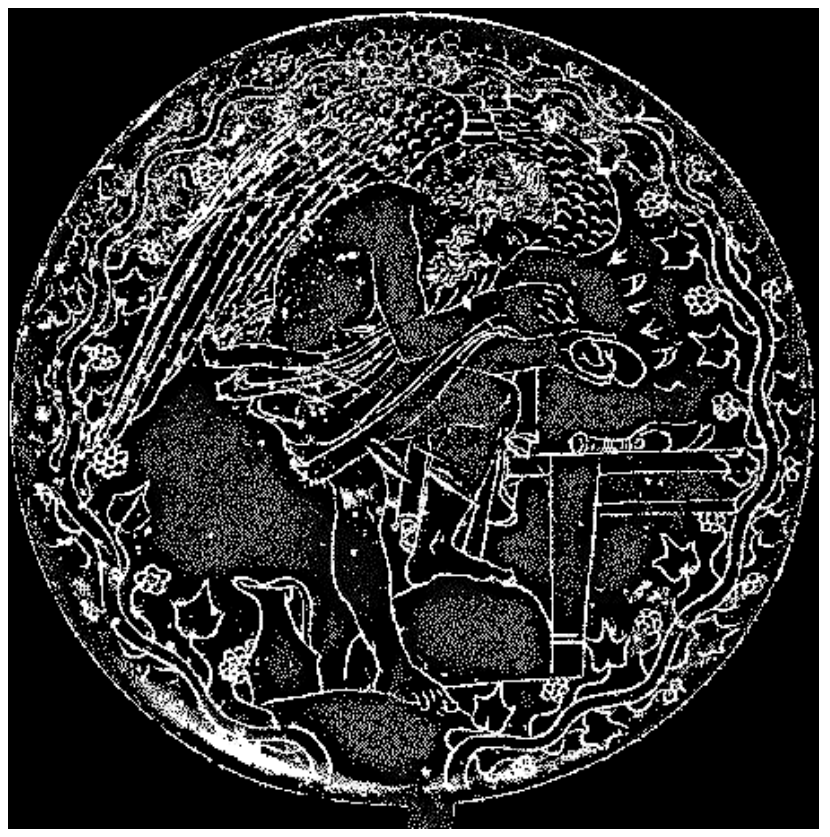

Fig. 2 Etruscan Bronze Mirror of Chalchas the Seer Reading a Liver (Vatican: Gregorian Museum, Rome, cat \# 12240)

Holy seers (mánteis): divine madness (manía) and melancholy

The diviners belong to the great family of the holy seers, thought in the ancient Greek world to have been endowed with mantic inspiration, a state of divine madness or possession. Pythias was one of these seers (mánteis) raving (manikoí) in madness (manía), and able to communicate with the divine. In a state of mantic 
inspiration, these human agents were "beside themselves" (ekstatikoi), but "full of God" (entheol), that is, "enthusiastic." But it was only in such state of being that were they able to say things impossible otherwise to utter in a normal state, having thus access to some truth (Tim. 71e).) For Plato the poet is the recipient of higher inspiration. "There is ... an ancient saying - constantly repeated by ourselves and endorsed by every one else - that whenever the poet is seated on the Muse's tripod, he is not in his senses, but resembles a fountain, which gives free discourse to the upward rush of water" (Laws 719c. Plato was aware of the power of the poet, therefore he was to be banished from the perfect city. Plato dedicated the dialogue Ion to poetic inspiration, and treated the subject in such dialogues as the Apology, the Menon, and the Phaedrus. The origin of the concept of poetic madness could be traced back to old Greek music and the Pythagoreans (KOLLER 1954, pp. 126ff, 148ff). But for the Pythagoreans, possession (mania) was a sickness to cure, not necessarily a divine gift to cultivate. Purification (katharsis) of the soul through the incantatory power of music was thought to be the cure of such illness.

Divine inspiration was perceived also as a gift given to the melancholic subjects. This idea pervades the history of culture since antiquity up to the Renaissance philosophy of Ficino De vita triplici, and later to be found in Robert Burton's Anatomy of Melancholy. One particular aspect related to the physiology of disease is most relevant for our research, namely, the humour which was associated with melancholy. A brief etymological note on the Greek word chólos might be instructive. This term, usually translated as "wrath," and synonymous to anger and madness, is also connected to another form of the un-Homeric cholé, which means "bile," causing melancholic disturbances. The surplus of black bile made one dispose to frenzy and divine inspiration achieved in music and poetry, according to Plato. In the dialogue Phaedrus Socrates states, "...in fact frenzy, provided it comes as the gift of heaven, is the channel by which we receive the greatest blessings." 3

Among the inspired artists, Michelangelo stands out with his theme of the melancholy genius possessed by divine inspiration and emotional instability. In one of his drawings, suggestively entitled II Sogno (around 1533), preserved in the collection of the Courtauld Institute of Art, Michelangelo seems to combine the Platonic notion of divine furor with the Aristotelian definition of melancholy. Gifts and vices are depicted in a cloud around the central figure (Fig. 3). Most importantly, the melancholy vision is a dream vision. Like the dream space of the chôra from the

${ }^{3}$ PLATO, Phaedrus and Letters VII and VIII (trans. by Walter Hamilton), London: Penguin Books, 1973, p. 46. 
Timaeus, the vision of the melancholy stands outside the diurnal logic of reason, in the sleep of the night. Michelangelo was indebted in his vision to Marcilio Ficino (himself inspired by Plato), for whom melancholy had two natures, described in De vita triplici as, the one a medical pathology in which the humour just sits there, the other a spiritual nirvana in which the humour fiercely burns.

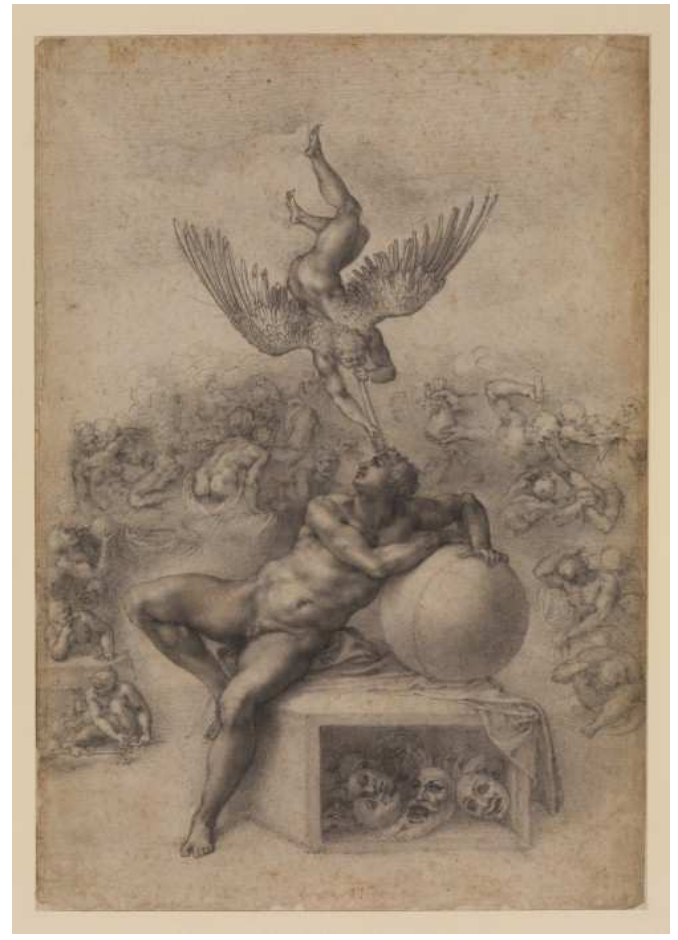

Fig. 3 Michelangelo II Sogno -

Drawing around 1511 (Collection of the Courtauld Institute of Art)

Chôra and the semiotized being - a "subject on trial"4

I tried to sketch out so far the relation between the chôra and illness as it comes out from Plato's texts, according to the access to some truth given to man through divination and inspiration. A specific human typology, subject to disturbances and vibrations (seismous) taking place in the chôra, came out in the process. I have identified the poet, the diviner and the melancholy artist, manifested as channels of some exceptional inspiration. Their response appeared to be a discourse beyond logic, and cognition: the prophetic discourse, and the poetic discourse (furor poeticus) characteristic of the poet and the melancholy artist. I will now search for

${ }^{4}$ This is allusion to Kristeva's theory of the subject, with its emphasis on the sujet-en-procès (subject-in process/on trial). 
an answer to the question of what light this relationship between the chôra and illness might shed on human creativity, and if we could think of creation as a symptom of defence against illness. For this, I must turn to Kristeva. I will try to briefly inquire first into what is the relation between the semiotic, the symbolic, and chôra in the signifying process that constitutes language, as presented by Kristeva in Revolution in Poetic Language; then I will consider the possible relation between illness and the abject, the concept presented by Kristeva in her Powers of Horror, finally to ask the question: Can the negativity of chôra, which has been analyzed by Kristeva as comparable to the negative forces of abjection, find some association with creation and genius in the aetiology of disease discussed in this article?

According to Kristeva, the semiotic and the symbolic are two inseparable modalities in the signifying process of language because the subject is always both semiotic and symbolic. Such is the psychoanalytic sujet en process (subject in process/in trial) - a subject interminably in process/on trial between the semiotic and symbolic. Kristeva borrows the term chôra from Plato's Timaeus to define the original ground of signification. For Kristeva, "the semiotic chora" (KRISTEVA 1984, p. 36) precedes the ego thinking, that is, it exists before Meaning exists. But chôra is the necessary ground; it is a pulsational force of bodily drives per se, essential to the functioning of sign and signification (TAUSSIG 1993, p. 36). Chôra is "a nonexpressive totality formed by the drives and their stases in a motility" (KRISTEVA 1984: p. 25). The "drives," which are energy, move through the body of the subject, and they are "always already in a semiotic process" (KRISTEVA 1984, p. 36). The "drives" are ambiguous, simultaneously assimilating and destructive. Kristeva is indebted at this point to Freudian and Lacanian notions of the unconscious, the drives and primary processes that articulate the fragmented substance, not yet constituted as the body of the subject (KRISTEVA 1964, pp. 17, 22-25, 30). Neither sign nor signifier, neither model nor copy, chôra is a process analogous to vocal or kinetic rhythm, which is constantly to be restored (KRISTEVA 1984, p. 26). In short, chôra is a space of instability and duplicity, uncertainty and hesitation, and this dualism of the chôra, represented as a tetrad or a double helix, makes the semiotized body a place of permanent scission. ${ }^{5}$ In her Powers of Horror: An Essay on Abjection (1982) Kristeva makes use of the theory of the subject in process and introduces the term "abjection" to define the chaotic, unformed maternal womb, which gives rise to language, the process through which the separation of the subject from object is made. The genesis of the subject occurs in the two phases of the thetic (the mirror

${ }^{5}$ My emphasis. For Kristeva, the scission in the psyche between life and death, meaning and nonmeaning is a symptom of melancholy, best expressed in Holbein's Dead Christ. 
stage and castration.), where the thetic (the rupture and/or boundary) is the irruption of the symbolic, the break with the semiotic. Thus, the genesis of the subject occurs as a violent rupture and/or boundary with the unconscious or the semiotic chôra. The poet "is" the subject in process/on trial (en process). He dwells with this rupture, at this boundary. He is comparable, according to Kristeva, to a scapegoat. Therefore, in Dennis King Kennan's view, the genesis of the subject is "a scene of sacrifice" (Question of Sacrifice, p. 33). This "event" of sacrifice, the poetic revolution (which Kristeva clearly distinguishes from art as a mere cultural form of human activity) is the interval/ the passage from semiotic violence to symbolic order.

Let us return one last time to our human subjects under scrutiny in this paper and look at them from this perspective. The poet, the inspired mántis, and the melancholy artist, they are all facing the negativity process of the chôra in which drives are manifested, facing simultaneously the semiotic (unconscious), as well as the symbolic.6 In this dramatic process, creation emerges as a process of transformation of the semiotic into the symbolic, which is always a process of becoming - a process, the process of creation. Fighting against illness, the mantic subjects confront permanently the chôra, turning into an asset what is a lacuna in the body, converting illness into creativity. The body of these mánteis is a "semiotized" body, which lives in a permanent "state of scission," to use Kristeva's syntagm; they are sujets en procès, subjects on trial, as it were. The space of creation and mantic inspiration has some kinship to the Platonic metaxý (the interval), where the daimôn ${ }^{8}$ dwells, or a revelation of some kind always occurs. This space of dream and imagination is a phantasm, a mirror image, a reflection; therefore it must be assiduously polished according to the choral technique (VITRAY-MEYEROVITCH 1978, pp. 38-39). Paraphrasing Derrida, we can also say that these human subjects belong to the genus of those who have no place (DERRIDA 1995, p. 108), because their discourse takes place in the chôra, which is the place of no place, the space of absence by excellence. Illness and absence - evoked in the epigraphê of the platonic dialogue, as well as of this article - are hopefully coming now to some logical association.

6 Kristeva calls this process of charges and stases a negativity. Chora is the place where the subject is both generated and negated - a fundamental lack.

${ }^{7}$ Lacuna is a gap or a missing part, an absence of some kind. In our case it refers to the state of illness.

8 In Plato's words from Symposium: "A great daimôn, for the whole of the daimonic is between (metaxy) god and mortal". 
Conclusion

Finally: last words on the act of creation as pharmakon, an "event" of sacrifice and a therapy. The therapy suggested by Plato for the restoration of symmetry and balance between soul and body is an imitation of the nurse chôra. This consists of never allowing the body to rest but moving it with a seismic movement, continually producing internal vibrations (Tim. 88e), coming thus close to the likeness of the archetype. This therapy is an ongoing process in which man should constantly imitate "the nurse of the universe" (Tim. 88d), the cosmic chôra. Kristeva's view of art as the means, by which "the flow of jouissance" infiltrates the symbolic order (KRISTEVA 1984, p. 79), is most instructive. If creation is, like its human subject, on trial, basically consisting in constantly confronting the choraic motility of the semiotic violent chôra, then creation is that flow of jouissance that is not only therapeutic, but which could epiphanically and episodically reflect the archetype. One may ask oneself whether this artist found under his work, possessed by it, not possessing it, 9 is the kind of artist of whom Jung thinks as the sole mediator by which the existence of archetypes could be demonstrated? As Jung puts it: "...this is the secret of creation. The process of creation, as much as we can grasp it, consists in the unconscious animation of the archetype, in shaping and polishing it until one achieves the perfect work." 10 Chôra was certainly one of those archetypes with cosmic vocation, revealed and animated in the process of human creation and imagination, but only obliquely, as a reflection in a mirror, as a dream, like the cosmic chôra itself. But chôra was both the paradigm of creation, and the space of human creation itself, because she was both embedded within the confines of the cosmos, as well as of the human body.

9 Jung distinguishes between the work of art, which derives entirely from the intention of the artist. In this activity, the poet is one with the process of creation; he is the process of creation itself. On the other hand, says Jung, there is a specie of work of art, which is imposed to the artist, in which the artist is possessed by it, his consciousness is empty in the presence of such phenomenon, he has the perception that he is under the work, or aside it, "like a person who find himself to be in the sphere of attraction of a foreign person." (C. G. JUNG, "La psychologie analytique dans ses rapports avec l'oeuvre poétique," Essais de psychologie analytique, Paris, 1951, pp. 127-128) See also, Anca OROVEANU, The European Theory of Art and Psychoanalysis (in Romanian), Editura Meridiane, 2000, esp. pp. 219-243

10 lbidem, p. 145. 


\section{References}

DERRIDA, Jacques: "Khora" in On the Name, ed. Thomas Dutoit, tr. David Wood, John P. Leavey, and Ian Mcleod, Stanford: Stanford University Press 1995, Translation of Derrida, Jacques 1993: Khôra. Paris: Galilée.

DE PUMA, Richard Daniel; W. K. C. GUTHRIE: "An Etruscan Mirror with the Prophesying Head of Orpheus," in Record of the Art Museum, Princeton University, vol. 60. (2001), pp. 18-29.

ELIADE, Mircea: Shamanism: Archaic Techniques of Ecstasy, tr. Willard R. Trask, London: Routledge and Kegan Paul 1964.

KLIBANSKI, R., PANOFSKY, E. and SAXL, F.: Saturn and Melancholy. Studies in the History of Natural Philosophy, Religion, and Art. New York: Basic Books 1964.

KOLLER, Hermann: Die Mimesis in der Antike, Bern 1954.

KRISTEVA, Julia: Powers of Horror: An Essay on Abjection, tr. Leon S. Roudiez, New York: Columbia University Press 1982.

KRISTEVA, Julia: Revolution in Poetic Language, tr. Margaret Waller, Columbia University Press 1984.

KRISTEVA, Julia: Soleil Noir. Dépression et mélancholie, Paris: Gallimard, 1987.

JUNG, C. J., The Archetypes and the Collective Unconciousness (1934-55), C.W.9, P.I. ; 1968.

MANOLESCU, Anca: The Pilgrim's place. The symbolic of space in Eastern Christianity (in Romanian), Bucuresti: Paideia 2001.

MILLER, Harold W.: "The Aetiology of Disease in Plato's Timaeus," in Transactions and Proceedings of the American Philological Association, vol. 93. (1962), pp. 175-187.

ONIANS, R. B.: The Origins of European Thought. About the Body, the Mind, the Soul, the World Time, and Fate, Cambridge University Press 1954.

OROVEANU, Anca: The European Theory of Art and Psychoanalysis (in Romanian), Bucurest: Editura Meridiane, 2000, esp. pp. 219-243. 
PLATO: Timaeus, in Plato: Timaeus, Critias, Cleitophon, Menexenus, Epistles tr. R. G. Bury, Loeb Classical Library No. 234 (January 1, 1929), Harvard University Press.

SALLIS, John: Chorology: On Beginning in Plato's Timaeus, Indianapolis: Indiana University Press, 1999.

TAUSSIG, Michael: Mimesis and Alterity: Mimesis and Alterity. A Particular History of the Senses, New York: Routledge 1993.

TIGERSTEDT E. N.: "Furor Poeticus: Poetic Inspiration in Greek Literature before Democritus and Plato," in Journal of the History of Ideas, vol. 31, nr. 2. (Apr.-Jun., 1970), pp. 163-178. VITRAY-MEYEROVITCH, Eva de.: Anthologie du soufisme, Paris : Sindbad 1978.

About the author:

Nicoletta Isar is Associate Professor at the Institute of Art History, Department of Arts and Cultural Studies at Copenhagen University. Visual Anthropology is both, her area of research, and of teaching, which combines visual arts, anthropology, and ritual performances, as well as elements of psychology. Her current research project is Comparative Chorography - A performative paradigm of creation and imagination a comparative study in the history of mentalities and visuality, concerned with the paradigmatic dimension of image and imagination, and creativity.

E-mail: isar@hum.ku.dk 